\title{
Method to Elicit Local Wisdom in Perceiving the Transformation of Historical Living Environment
}

\author{
Widya Fransiska F. Anwar', Ismail Said ${ }^{2}$, Dilhsan R Ossen ${ }^{3}$ and Muh. \\ Hisyam Rasyidi ${ }^{4}$
}

${ }^{1}$ PhD Candidate, Faculty of Built Environment, University Teknologi Malaysia, Lecturer, ' Dept of Architecture, Sriwijaya Unversity

${ }^{2}$ Assoc Prof, Faculty of Built Environment, University Teknologi Malaysia

3, 4 Senior Lecturer, Faculty of Built Environment, University Teknologi Malaysia

widyafrans76@yahoo.com ${ }^{1}$

\begin{abstract}
The study aim is to develop method of rebuilding identity study based by eliciting residents' opinions on the historical riverside settlement in Palembang pertaining to the changing morphology of the city form. The objectives of this study include(1) literature review on analysis method on urban form transformationand people perception on urban and social transformation and (2) developing research method to the rebuilding identity study. This paper answers the question of what method can be used to analyze the identity of Palembang riverside settlement based on the change of locals' perceptions on urban and social transformation. By comparing the previous studies on the aspects ofthe identity, the result shows thatby triangulating the previous method from urban morphology and people perception study is the proper method for rebuilding identity of riverside settlement. Paper concludes that the interdependency betweenurban morphology and people-place emotional bonding is a partof local wisdom that generates the identity of historical living environment.
\end{abstract}

Keywords: morphology, emotional bonding, place identity, peopleperception

\section{Introduction}

Like other old city in Indonesia, riverside area is the first location of city emergence. After so many years, the physical and spatial structure of this area had been marked by the various human civilizations within periods. As the city developed into modern one, the traces of past human civilization remaining at riverside living environment show how the area had been transforming from time to time. The transformation occurred in this area can be seen into two ways; physical and psychological. Physically, the living environment accommodated the changes in living activity. Psychologically, the one's perception towards the living environmentis influenced by the changing activities and experiences at the place. The transformation also happened as the result of the development of human civilization, one of this was acculturation of different cultures. The first community who founded the city had their life system that was forming the origin physical- spatial order of Palembang living environment. When the nonnative came and interacted with the natives, the origin life system had been influenced by the new comers' life system. The new system changed theorigin 
physical- spatial order of environment and created the new living environment.The process of recreating new living environment was happened continuously. The result of this process was expressed in the physical-spatial setting of living environment.

Palembang was founded in $683^{1}$. As it is an old city, the riverside urban structure reflects the system life transformation, as well as the identity of riverside area. Within this long period of time, the transformation, the identity of riverside gradually transformed by the modernization destructing much of the urban and social structures of its original landscape, and perhaps, the perception of its residents towards the city identity. This paper is a theoretical exploration which aims to develop method of rebuilding identity study based by eliciting residents' opinions on the historical riverside settlement in Palembang pertaining to the changing morphology of the city form. The objectives of this study include (1) literature review on analysis method on urban form transformation and people perception on urban and social transformation and (2) developing research method to rebuilding identity study.

This paper answers the question of what method can be used to analyze the identity of Palembang riverside settlement based on the change of locals' perceptions on urban and social transformation. The problem faced in answering this research question is the urban and social transformation which had happened within a long period of time, from the era of Sultanate Palembang Darussalam (1700s) until now. For urban transformation investigation, this study uses the time series map as the main sources of data. Meanwhile to understand the people perception change needs comprehensive information including the past and current people perception. Therefore, this paper will be divided into three parts. In the first part, paper elaborates the basic understanding of the relationship between (1) place and identity and (2) people and place, to obtainthe considered aspect in rebuilding identity study. The second part was explaining Palembang as the context of rebuilding identity study. It is a combination of historical explanation to show how the city had been developed from the past. The third part was an elaboration of the related previous study on rebuilding identity study, which consisted of urban morphology and people perception studies, including place attachment study. In this part, paper showed the previous methods of (1) investigating the change in physical and spatial setting to obtain the key urban element, (2) measuring the current people perception towards the riverside settlement and (3) investigating the past people perception on the old riverside settlement. Finally this part was ended by the developing research method for rebuilding identity study.

\section{Materials and Method}

\subsection{The concept of place and identity}

Identity means persistent sameness and unity that shows the distinctiveness or uniqueness and sustains in continuity (Breakswell, 1986; Jacobson-Widdung, 1983; Inn, 2004). Individually, the identity is a combination of self consciousness and the categorization of a person. The inner aspect of

\footnotetext{
${ }^{1}$ This is mentioned in Kedukan Bukit inscription, stated the founding of Sriwijaya in caka 604, 11 cuklapakca or 16 June 683 AD. (Pudjiastuti, 2006; Nurhan 2010)
} 
personal identity comes from the self hood as the way a person perceive himself such as conscious and unconscious ideals, preferences, goals, behavioral tendencies and skill. The outer aspects comes from outer values that influence a person's life such the society, social status, culture, belief, religion (Proshansky, 1978 in White et.al 2008; Ricoeur cf Gutwirth, 2009). Identity also relates to the how person associates himself with his living environment that describes his' socialization with the physical world(Ross and Uzzell, 1996).When individual identity relates to a certain place, it also as self categorization in terms of place and this is known as place identity (Lewicka, 2008) ${ }^{2}$.

However, the physical entities in the physical world also reflect the identity, which is known as the identity of a place.The physical entities can refer to a place or a set of a place that assure the place distinctiveness as unique character of a place. Through their setting, it reflects the life system accommodated in as it has been altered by human action over long periods of time (Rapoport, 2004). Through their meanings, it reflects the value that arise the sense of place to the people (Lewicka, 2008; Wang, 2010) ${ }^{3}$

To sum up, there are the two meanings of identity that are related to the place. Firstly is the place identity that refers to a person's association to a certain place. Secondly is the identity of a place which is related to the physical features that is a manifestation of certain place in the built environment. Like the place identity that comes from a person's perception on his self, the identity of place also comes as a result of a person's perception on the environment.

\subsection{People-place relationship studies}

Human action has altered the environment as action and reaction to the life system. The changes would be the physical change i.e. arrangement, material, space and the non-physical change i.e. meanings (Rapoport, 2004). By experiencing the place, a person is tied to the place, inform of emotional bonding.When the subjective feeling towards is experienced by people in community, the place will create the community emotional bonding to their place. These two conditions are called as place attachment.

The previous studies mentioned the place attachment as the description of the role of the place in people lives through subjective experience in form of positive connection of emotional and psychological relationship between individual or community and the environment (William and Vaske, 2003; Giuliani and Feldman, 1993; White et.al, 2008). Place attachment is happening in individual and community level. In these two kinds of level, place attachment shows the individual commitment and institutional ties between human and the place that is influenced by the life cycle (age, family status), length of stay and mobility(Stokol and Shumaker, 1981; Hummon, 1982).

Generally, the place attachment comes from the person and the surroundings. From personal feeling, place attachment consists of place identity and place dependence. Place identity shows how the emotional attachment, while place dependence shows the functional attachment. From the

\footnotetext{
${ }^{2}$ In Palembang, budak sungi is a common term can be used to describe the place identity. This term refer to a person who lives at riverside area. This term shows how a person put himself in the categorization of Palembang citizen who live at physical world of Musi riverside area.

3 In Palembang, the existence of Ampera Bridge is recognized as the identity of Palembang. It narrates the importance era of city development, especially road system that connects the two side of city.
} 
surroundings, people can attach to theplace by the awareness of the place value, adjustment of special place, assessment of the importance of development, community bonding andnature bonding. (William and Vaske, 2003; Brown and Raymond 2007; CM Raymond et.al, 2010)

To sum up, the people place relationship can be studied from the place attachment studies. The components of place attachment are place identity, place dependence, place value, special place, and assessment of physical development that come from individual, community and environment.

\subsection{Rebuilding identitystudy}

Aforementioned explanation on identity shows that there are a direct connection between the attachment and identity. Both come from the way individual or community perceiveshimself or themselves in associated with the place. In this situation, we can draw two aspects in studying the rebuilding identity of particular area, which are tangible and intangible aspects. The tangible refers to the physical entities in the place that become the unique character and distinct the place from others. The intangible refer to the way peopleperceive the place as meaningful elements in their living environment 4 . The transformation of these two aspects will influence one another. As the society develops, more people come to the area. The traditional landscape transforms as a result of the increasing heterogeneity of culture expression at the area. Eventhough the physical transformation is happened, some of variability will retained and form local character (Rapoport, 2004) ${ }^{5}$.

\subsection{Site Study}

Palembang is an old city with a long history. It was well known as the location of an international hub from the era of Sriwijaya Empire ( $7^{\text {th }}$ century). Like any other old cities in Nusantara archipelago, the city was started from the riverside area when the river was the main transportation line. After the Majapahit Empire conquered Sriwijaya in $14^{\text {th }}$ century, Majapahit could not rule the Palembang area de facto, since Palembang was occupied by the pirates for more than 200 years. When Majapahit Empire fell down, the new Islamic kingdom, Demak Sultanatewas born. As the time goes by, this sultanate could not avoid the internal conflict of succession. A group of the lose party, known as Demak refugee, went to Palembang and set up a new community with the first ruler Ki Gde Ing Suro. He successfully blended the native people and his group and formed a Malay-Java community (Hanafiah, 1995). The new ruler rebuilt Palembang as the center of government. Under Kimas Hindi, the third successor, the new authority was officially claimed itself as an independence authority in Palembang and later it was known as Palembang Darussalam Sultanate.

The history line of Palembang was developed along with the development of the city. There were four palaces built by the sultanate. The coming of the Dutch to colonize Palembang potency, made the three palaces had not existed

\footnotetext{
${ }^{4}$ The example of riverside settlement that consists of traditional Limas house and rafting house is an example of how this tangible entity creates Palembang uniqueness. The intangible atmosphere of riverside settlement that is created by narrow circulation path (wooden alley) between the big size wooden pillar buildingscreatessense of place for the residents.

5 The existence of riverside settlement in Palembang is one example of the retained physical entities even thought the modernization has influenced the city's life
} 
anymore, burn by the Dutch. The last palace was known as Kuto Besak, a fortified city. In the era of Sultan Mahmud Badaruddin I (1780s), Sultan had policy on city physical development. There were so many buildings development, like the palace, the great mosque, the royal cemetery and the zone of settlement. This affected the Palembang urban form and its identity as aninternational harborcity become stronger. Besides built some monumental buildings, the Sultan also had placed a land use policy. He divided the main zone of the city into two areas, Ilir and Ulu. He put the Ilir area as the higher value land based on past philosophy ${ }^{6}$. Further, he allocated the royal family and the natives to have a place in Ilir areawhile the non-natives were placed at Ulu area. He also ruled that only the natives and honored family could have a place on land. As a defense strategy, he only allowed the foreigner to stay on the water so he could prepare the action of any threat come infrom the outsiders (Taim, 2002; Utomo, 2006).

As the Dutch occupied Palembang, the urban form was influenced by them.At the same time, the road system was built in 1900s that led the city into another urban transformation. The development of infrastructure to accommodate of Dutch communitywas the new era of city development which had changed the orientation to the land.

In independence era, the urban structure of Palembang is continuing. The development of Ampera Bridge that finished in 1965 contributed to the urban structure that put more orientation to the land development. Currently, the land development at Ilir area dominates the city and it neglects the urban development at riverside area. Riverside area that was fulfilled with traditional and historical urban elements was declining and abandoned. Starting from the late of 1990s, the local authority of Palembang started to reemerge the city historical potency by rehabilitating many historical monumental buildings and the area of riverside settlements. As a part of the city assets, the unique character of river city of Palembang was reintroduced and rebuilt.

\section{Result and Discussion: Developing method for the rebuilding identity study}

\subsection{The previous method of identity studies}

As mentioned before, the identity is related to what people perceive about their place or environment. This comes from the psychological aspects of human, such positive emotional feeling on the place. The studies in place attachment discuss on this psychological aspect. Thedevelopment of place attachment theory had been doneby some scholars to find its definition. They also develop the method to measure the degree of attachment as showed in figure 1.

Starting by psychometric measurement, William and Vaske (2003) explored the item related to place attachment including the basic questions used in their survey questionnaires. They measure the degree of attachment based on the respondents' answer on some formulated questions. The question itself had been tested its generability, and then it can be used to measure the place attachment in any other places. Basically, the William and Vaske's study

\footnotetext{
${ }^{6}$ Since era of pre-Sriwijaya, the Ilir area had been perceived as the higher value because the level of Ilir was higher than Ulu. In Ilir area, there is located the highest level of land in Palembang, named Bukit Siguntang. When Palembang was a Buddhism center of study, the philosophy of highest land as the holy land had already applied in the old Malay society.
} 
elaborated the place identity and place dependence as two items of place attachment. In place identity, they measured how a person loves particular place related to the emotional bonding to the place. It drew the attachment from the feeling of being a part of the place and being reflected by the place. In place dependence, they measured a person attachments based on the function accommodated by the place. It focused on the level of satisfaction toward the place. This study did not clearly differentiate what kind of activity could be measured for place dependence. Mowen, et.al (1998) investigated a typology of place attachment and related it with the activity involvement. He mentioned in his study that the outdoor activities could determine level of attachment of visitors towards a natural park.

In 2007, Brown and Raymond (2007) improved what William and Vaske had been done by comparing the psychometric measurement and map based measurement to measure the place attachment of Otway region. In their map based method, they measured the attachment by investigating the people awareness on place value, special place, and the importance of development. They findings mentioned that these two methods can be utilized in measuring the place attachment.

Adding to the previous studies, Raymond et.al (2010) proposedthe dimensions of place attachment that were raised from three poles of bonding; personal, community and environment. He mentioned that the place identity and place dependence come from the personal bonding. Healso mentioned that community could raise the place attachment through family and friend bonding. Responding to the wild environment, he mentioned that the environment could create the nature bonding. He also limited the nature bonding to be applied for people who lived in rural area.

Thosestudies are used to measure the way people perceive the environment in current context. People were questioned through a list of questions to measure their attachment to the place. In order to investigate how past people perceive their living environment; some related method from iconography studies can be modified and utilized to accomplish the research objectives. The identity study on tourism formulated that the destination identity can be measured through image study. The image in form of paintings and images is investigated by learning the motifs appeared in the images, observing the physical arrangement of each element in the images, and defining the context and theme of the situation grab by the image (Govers and Go, 2005). 


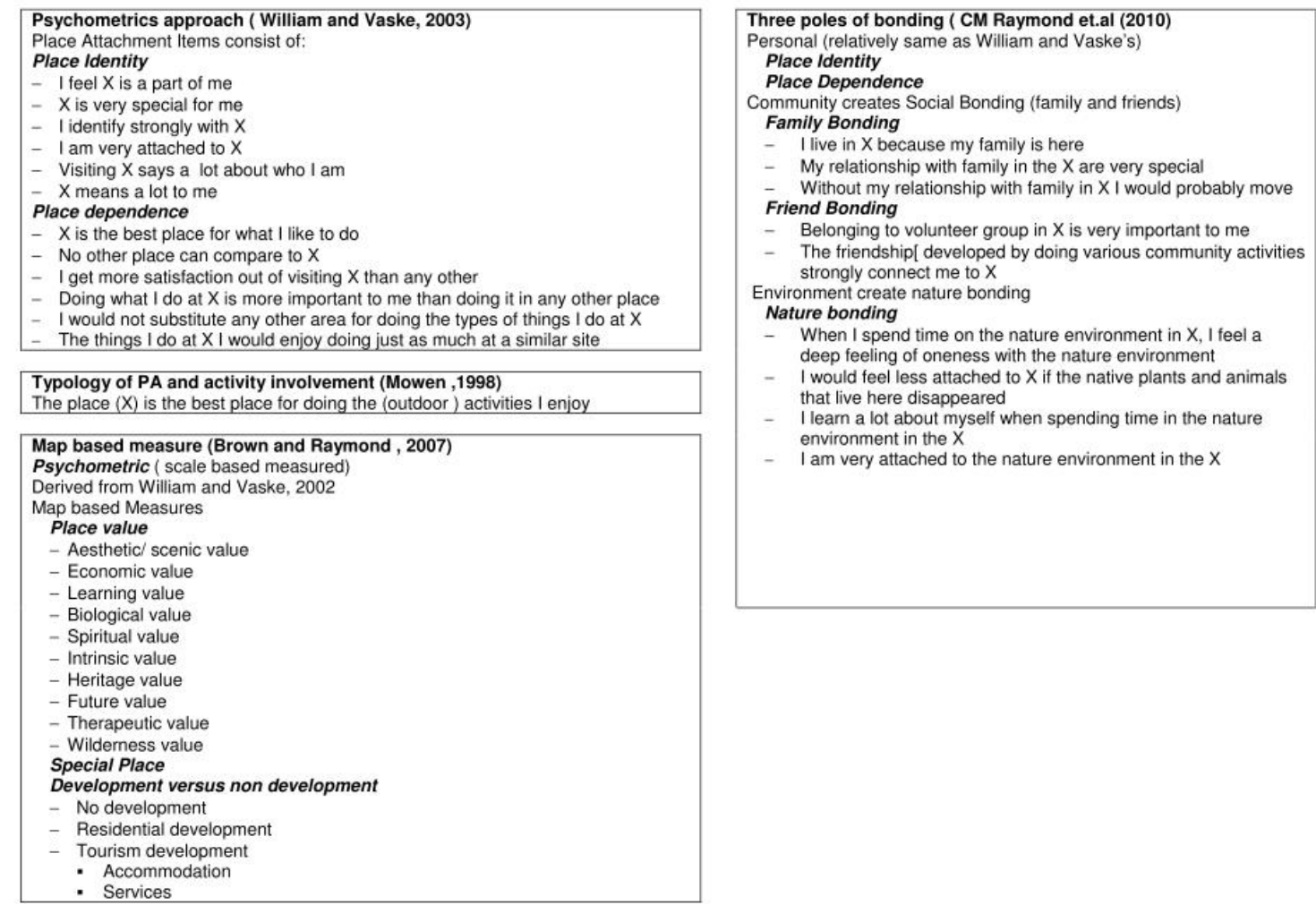

Figure 1: The Development of Attachment Measurement Method

\section{2. $\quad$ The method used for the rebuilding identity study}

\subsubsection{TheFrame Work of Rebuilding Identity Study}

Handal(2006) mentioned that the place identity can also be defined as the process of building and rebuilding meaning in a space continuum. This process comes from the emotive, the strong feeling because of culture, belief, history that formed and reformed by the rational forces. Her study on historic site of Bethlehem comes out with the conclusion that the historic cites must be protected by balancing these two emotive and rational forces. In other words, she mentioned that rebuilding the identity of historic site can be done by protecting the identity and accommodating the future changes.

Place identity is also an asset for the place, in the context of a city; it is an asset for the city that differentiates the city from others (physiognomy). The rebuilding city identity is one of making the place assets promotes city's specific advantage and attractiveness and civic pride. (Gospodini, 2004; Inn, 2004; Moller and Radloff, 2010)

It is very important and advantageous for a place to rebuild its identity. The locality derived from the distinctiveness or uniqueness of the character of the place brings up the civic pride of their place. The way people perceive themselves in associated to the place will direct the direction of physical and social development of their place. This is where the local wisdom of the people takes into account in maintaining and protecting their built environment. Therefore, to study on rebuilding identity of Palembang, it is important to elicit residents' opinions on the historical riverside settlement in Palembang pertaining to the changing morphology of the city form. 
The rebuilding identity study must consider the tangible and intangible aspects of identity. This is done by elaborating the urban form transformation and studying locals' perception on urban and social transformation. The first objective can be done through morphology study of riverside settlement urban form. By analyzing a series of maps, the urban transformation can identify the key urban element that still existed until now. The second objective demands more complicated effort, since it investigatesthe local's perception on the urban and social transformation occurred in historical riverside area. This means that there is a need to investigate the past and current people perception on the area. For past people's perception, the method from iconography study can be utilized. By observing the motifs, physical arrangement, context and theme in the old paintings and photos, the identity of old Palembang can be measured. For current people's perception, the method derived from place attachment studies can be utilized. From the component of place attachment stated in previous studies, the measurement of place identity, place dependence, familiarity, place value, special place and the importance of development are suitable for Palembang's case. This also should be supported by theinformation of the respondents such demographic profile to see the respondents'familiarity and experience-use towards the place.

From the steps, the study will obtain the interdependency between the urban elements and urban identity. The existence of key elements showed in the morphology pattern will be rechecked by its existence in people's mind through the investigation of past and current people perception. By having this, the study will obtain the factors that contribute to the remaining perception of the place. At the end, this will give new contribution to the study of identity. The frame work of rebuilding identity study is shown in figure 2 .

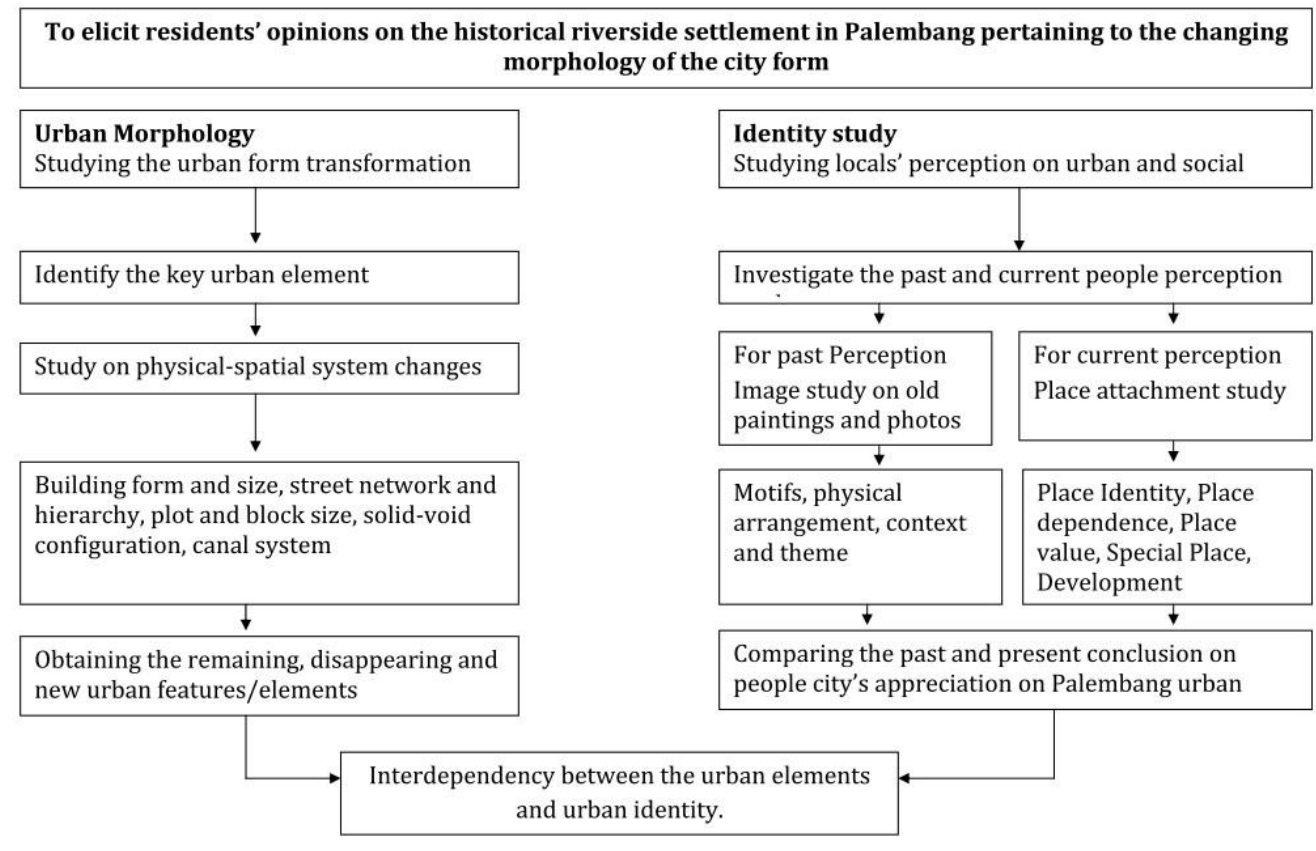

Figure 2: The Frame Work of Rebuilding Identity Study in Palembang Historical Riverside Settlement Context 


\subsubsection{Eliciting the Local Wisdom in the RebuildingIdentity Study}

Usually the local wisdom can be found in form of poetry, beliefs, myths, and any other local knowledge. Sartini (2004) defined local wisdom as ideas coming from local with philosophy of wisdom and good value which is applied, embedded, rooted and followed by the society. It another word local wisdom embedded in the local culture in the society life system. It is repeated and reinforced continuously because of its good value for society. This locality is a result of genius thinking (local genius) of the society that make the society able to absorb, adapt, and manage the non-local culture based on genuine value in the society. More over the local wisdom represents local knowledge based on local culture. It can be perceived trough people's everyday life, because it ends on the tradition. It is also a result of common response on the environment.Beside its rootedness from society, the local wisdom is a result of the deep thinking process of the society leader and its follower. It consists of local knowledge and the genius thinking that forming the cultural identity of a society that direct the civilization. Function of local wisdom in society are various and mostly it is highlighted on becoming the control or references of society when deal with the new change in the life system. Furthermore, the local wisdom has ability to accommodate, integrate the non local culture coming from outside so that the social and physical development in the society can be directed and controlled (Moendardjito in Sartini, 2004).

Based on the definition and the function of local wisdom, it obviously can be seen that the relationship between the local wisdom and people perception. Local wisdom is the result of a deep thinking and it is received well by the people based on how they perceived it in their daily activities. This kind of people perception that is embedded in daily life becomes the value that commonly accepted and responded by the society (Ridwan, 2007).

Like study done by Chooncat(1999)it examined the use of peasants' perception to conserve the forest ecosystem. According to the peasants, they believe that forest ecosystem is holy thing. Using the local wisdom in form of punishment, belief and rule, to the men who destroy the forest, the preservation effort have made forest in northern Thailand become fertilized, especially in Karen and Lawa areas. In this study, the perceptions of the peasants towards the forest as holy place become the local idea that directing the preservation effort. The idea of forest as holy place is the local wisdom in this study.

In the rebuilding identity study of Palembang historical riverside settlement, the local wisdom of the residents should be explored more in order to find the local idea of the residents. Perception of the residents towards their living environment is a source of how people perceive the value embedded in their environment. How they value the place and how they response the new modern value based on the embedded value show what the local wisdom inherence at the Palembang historical riverside settlement is. The way person being attached to their environment shows the goodness of the embedded local value in the society, the goodness of their local wisdom.

In order to explore the local value towards the Palembang historical riverside settlement, the rebuilding identity study examines the change of people perception in its method, as shown in figure 2 . The study on the past and current people perception was explored in order to gain the remaining local idea in the 
society that directed and controlled the physical and spatial change in the historical riverside settlement. For past perception, an elaboration of old documents and paintings were used, while for current perception, the exploration of place-place relationship using the survey questionnaires and in depth interview to the residents were utilized. The results of these two method resulted in the local idea or belief of the residents. By comparing with the urban morphology change exploration, the results will be rechecked and strengthen. Thus the local value of riverside's residents becomes a strong tool to control and direct the modern physical development at Palembang historical riverside settlement.

\section{Conclusion}

Paper concludes that in order to see the interdependency between urban elements and urban identity, there is a need to consider what people perceive towards the urban elements and their configuration. The way people being attached to their place influence the emotional bind between people and place. The combination between study on the physical and psychological aspects of living environment in form of morphology and emotional bonding with the place is suitable method to generate the local perception on their old-historical environment. The method to elicit local wisdomby considering people perception towards the place shows how thelocal wisdom being utilized in controlling and protecting the historical living environment.

\section{Acknowledgement}

This paper is a part of doctoral study on rebuilding the identity study using urban morphology, conducted at Green Innovation Research Group, Faculty of Built Environment, Universiti Teknologi Malaysia.

\section{References}

Brown and Raymond (2007), The Relationship between Place Attachment and Landscape Values: Towards Mapping Place Attachment, Applied Geography, Elsevier, Vol.27 p.89-111

Chooncat (1999), Use Of Local Wisdom In Forest Conservation And The Ecological System To Solve The Problem Of Drought In Thailand, 1th Rajabath Institute, Bangkok, p.270-279

Gospodini (2004), Urban Morphology and Place Identity in European Cities: Built Heritage and Innovative Design, Journal Of Urban Design, Carfax Publishing, Vol. 9, No.2, p.225-248

Govers and Go (2005), Projected Destination Image Online; Website Content Analysis of Pictures and Text, Information Technology and Tourism, Vol. 7 , p.73-89,http://tourism.wu-wien.ac.at/Jitt/JITT 72 Govers Go.pdf

Gutwirth, (2009). Beyond Identity? Identity Journal, Springer, vol.1.p.123-133

Hanafiah (1995), Melayu Jawa, Citra budaya dan Sejarah Palembang, Raja Grafindo Persada, 1995. 
Handal, 2006, Rebuilding City Identity Through History: The Case of Bethlehem Palestine, Designing Sustainable Cities In The Developing World, Ashgate Publishing Co, England, p.51-68,.

Inn (20040, Plan for City Identity Establishment and City Marketing; the Case of Kimpo City, Dela 21, p.233-240, http://www.ff.unilj.si/oddelki/geo/publikacije/Dela/files/Dela 21/024\%20kim\%20inn.pdf

Lewicka (2008)Place Attachment, Place Identity And Place Memory: Restoring The Forgotten City Past, Journal of Environmental psychology, Elsevier, vol.28, p.209-231

Moller and Radloff (2010), Monitoring Perceptions of Social Progress and Pride of Place in a South African Community, Applied Research Quality, Springer, Vol.5, p.49-71.

Mowen, et. al (1998) A Typology of Place Attachment and Activity Involvement,http://www.nrs.fs.fed.us/pubs/gtr/gtr ne241/ gtr ne241 089.pdf

Rapoport, Amos, 2004, Local Environment in Global Context, Proceeding of EBRA 2001 International Symposium, 2004, p.1-15

Raymod, et.al (2010), The Measurement of Place Attachment, Personal, Community And Environmental Connection, Journal of Environment Psychology, Elsevier, Vol. 30, Issue 4, December 2010, p. 422-434,

Ridwan, N.A ( 2007 ),Landasan Keilmuan Kearifan Lokal, Jurnal Studi Islam dan Budaya, Vol.5 No.1. Jan Jun 2007, p.27-38

Ross and Uzzell (1996),Place and Identity Process, Journal of Environmental Psychology, Academic Press, Vol.16, p.205-220

Sartini (2004), Menggali Kearifan Local Nusantara, Sebuah Kajian Filsafat, Jurnal Filsafat, Agustus 2004, jilid 37 No. 2, p. 111-121

Taim (2002), Permukiman Tepi Sungai Kota Palembang Dari Masa Ke Masa, Jurnal Siddhayatra, Vol.7. No.2 November 2002, p.25-40

Utomo (2006), Tinggalan Budaya Masa Lampau Di Palembang, Manfaatnya Untuk Pengembangan Wisata Budaya Dalam Konteks IMT-GT, Jurnal Siddhayatra, Vol.11 No.1 November 2006, p1-12

Walker and Ryan, 2008, Place Attachment and Landscape Preservation in Rural New England: a Maine Case Study, Landscape and Urban Planning, Elsevier, vol.86, p.141-152

Wang, 2010, In Search Of Authenticity in Historic Cities in Transformation; The Case Of Pingyao, China, Asian Research Institute working paper series No. 133, ARI, NUS Singapore

White, et.al, 2008, Effects on Place Identity, Place Dependence and Experience Use History on Perception of Recreation Impacts in a Natural Setting, Environmental Management, Springer, Vol. 42, p.647-657 


$\begin{array}{ll}\text { Day \& Date } & : \text { Friday, November } 11^{\text {th }} 2011 \\ \text { Session } & : \text { Parallel Session } 5 \\ \text { Time } & : \text { 15.10-15.30 } \\ \text { Room } & : \text { C (Laika House) } \\ \text { Speaker } & : \text { Widya Fransiska F. Anwar } \\ \text { Speech/Paper Title } & : \text { Method to Elicit Local Wisdom in Perceiving the } \\ & \end{array}$

\section{GENERAL NOTES}

\section{DISCUSSION}

\section{Question Answer}

- What method did you use to find - Using investigate process, question the the people preception in the past people with questionnaire, and analyze and recent time? the data.

- What is the result of the research - It still in the process ofdata collection, that you do? so it have not finished yet, but the outline is that people from one side of the river depend on people from the other side of the river. 